\title{
Polski list romantyczny jako forma mówiona (w świetle korespondencji młodego Mickiewicza)
}

Grzegorz Szelwach 
nAPPS Seria XI $20(05$

Grzegorz Szelwach

\section{Polski list romantyczny jako forma mówiona (w świetle korespondencji młodego Mickiewicza)}

Pani Profesor Marcic Pininiskicj

\section{O języku i stylu listów młodych poetów romantycznych}

Wiclokrotnie w mojej pracy doktorskicj Listy Adama Mickienicza (lata 1817-1833) byly przywoływane ogólne charakterystyki listów Mickiewicza jako pełnych prostoty, postuniętej czasem wręcz do ,zgrzebności”, cytowalem sądy Marii Dernatowicz' i Marii Danilewiczowej $^{2}$ o wyzuciu ich z wszelkiej literackości. Zastanawiając się nad tą cechą korespondencji Mickiewicza, wiązalem ją z jego znaną powściągliwością: ogólnie wiadomo, że Mickiewicz na temat swej twórczości nie wypowiadał się wicle, a im był dojrzalszy, tym silniej unikal wszelkiego „poetyzowania” w korespondencji. Prostota z listów poety płynic - wyrażałem przypuszczenie - z jego pragnicnia, by w listach do bliskich sobie osób być tylko czlowiekiem prywatnym, nie ,polskim Byronem”, ani „wieszczem”, a wreszcie z programowej spontaniczności, z jaką pisywal często swe listy.

Inaczej jednak rzecz się przedstawia w okresie wileńsko-kowieńskim. W tym czasie Mickiewicz, podobnie jak jego adresaci, traktował nierzadko pisanie listów wręcz jako wprawianie się w pisarstwie: znajdujemy w nich fragmenty prozy w stylu Sterne’a, bądź też obyczajowe obrazki. Pod tyn względem blok listów poety ma cechy charakterystyczne dla

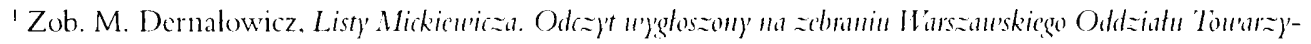
stu'a Literackicgo im. Adama Mickicuica w dn. 15 XI1 1993, . Rocznik TLiAM"28: 1993, s. 97-108.

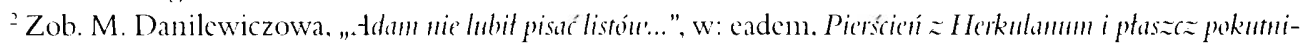
c. Szkice literackic. Londyn 1960, s. 87-107. 
calej korespondencji filomatów. Dlatego wyróżniam ten blok korespondencji i poświęcam mu niniejszy tekst.

Młody Mickiewicz mial jasną świadomość rozmaitych możliwości stylistycznych i różnych tonacji emocjonalnych, jakie otwiera list jako gatunek literacki. Świadczy o tym doskonale list z sierpnia 1819 roku do Jana Czeczota:

Oświadczeniami przyjaźni zapchać ćwiartkę jest dla mnie, a zapewne i dla ciebie nudną rzeczą (...) napisać poetycko-konceptowato, ażeby i siebie, i ciebie zabawić, nie zawsze się uda. (...) Chciałem nawet listownie improwizować, ale że listownie, że ty nie jesteś w równym humorze, lepiej prozaikować3.

Jakże to różny list dwudziestojednoletniego Mickiewicza od listów jeszcze niedawno, przed dwoma laty, pisanych do Czeczota. Te dwa najwcześniejsze listy - z czerwca ${ }^{4}$ i z lipca 1817 rok $u^{5}$ - są pełne emfazy i patosu z powodu rozstania z młodzieńczą miłością: Anielą. Stychać w nich lekturę Noucej Heloiz): „Plakaliśmy dlugo oboje”; „Tragiczna ta akcja". To russoizmy, sentymentalizm, wyznania, lubowanie się w nieszczęściu milosnym. Składuia tych listów jest staroświecka, to mieszanina patosu i niezręczności ${ }^{6}$, takie zdania brzmią sztucznie, i dzisiaj odbiera się je jako zafałszowane.

Wspomniane dwa listy do Czeczota uwidaczniaja, jak skonwencjonalizowanego języka używal niespełna dziewiętnastoletni Mickiewicz, pisząc do przyjaciela o swoich przygodach miłosnych.

Gdy porównamy list dziewiętnastoletniego Mickiewicza z listami Slowackiego czy Krasińskiego z czasów, gdy mieli oni tyle samo lat, widać ogromną różnicę między młodymi ludźmi, którzy byli staramnie wychowywani w domach elity kulturalnej, których uczyli dobierani guwernerzy, a od wczesnego dzieciństwa zaprawiano ich w pracach i zabawach literackich. Mimo legendy o poemacie na temat pożaru Nowogródka, jaki podobno stworzyt Mickiewicz w dzieciństwie, mimo iż jego ojciec miał pewną kulturę literacką, Mickiewicz nie wyniósł z domu tyle światowego poloru co tamci dwaj. O wiele więcej zawdzięczal Uniwersytetowi, Towarzystwu Filomatów, a wreszcie samemu sobie.

Bardzo szybko rozwijał się zresztą, kształcił się także towarzysko, nabierał ogólnego obycia, które widoczne jest w obyczajach, i właśnie w toku i w swobodzie korespondowania.

30 Jana Czeczota, Milaszewo, 2/1+ VIII 1819. cyt. za: A. Mickicwicz, Dzicta. Wydanic Rocznicowe 1798-1998, red. Z. J. Nowak, Z. Stefanowska, Cz. Zgorzclski, od t. 3: M. Prussak. t. 14: Listy, opr. M. Dernatowicz, E. Jaworska. M. Ziclińska. Warszawa 1998. s. 33: przy dalszych cytatach paginacja tego tomu w naviasic.

+ Do Jana Czeczota. Wilno. 25 VI/7 V1I 1817 (s. 15).

${ }^{5}$ Do Jana Czeczota, Wilno. $5 / 17$ VII 1817 (s. 16).

"Nic mogę przcto zgodzić się ze zdanicm Anny Kalkowskicj, Struktumia sktadniou'a listu. Wrochaw 1982, iż .listy Mickicwicza są przykladem racjonalnego. znormalizowanego toku, również w okresie mlodzieńczym, kiedy powstawal kanon naszej literatury romantycznej" (s. 1+4). 
Słowacki dwudziestoletni pisze zręcznie, elegancko, „światowo”, stara się o błyskotliwość, potrafi ubiegać się o względy odbiorcy. Wskazuje to na duze obycic salonowe. Poeta umie pobudzić ciekawość odbiorcy. Widać, że jest wtopiony w towarzystwo.

14 stycznia 1829 roku pisze do Aleksandry Bécu:

Kochana Olesiu! Na ręce Twoje posylam list do pana Śniadeckiego Jana, jak mi się zdaje, dosyć grzecznie napisany, prosząc go o danie mi potrzebnych rad i o rekomendacyjne listy. Chciałem prosto do niego list adresować, ale nie wiedziałem, gdzie jest teraz — czy na wsi, czy w mieście. Zajmij się, proszę Ciebie, kochana Olesiu, przesłaniem mu tego listı, a jeżeli będziesz mogla, to proś. żeby się z przesłaniem mi listów nie spóźniał. (...) Donoszę ci także, żenn pisząc do nicgo nie wymienił osób, którym chcę być przedstawionym - wiesz bowiem, że ani ja, ani nikt z tutejszych nie wie, kto w Warszawie najwięcej może być pomocny: ja zaś nie tylko o takie listy proszę, które by ni w dopięciu jakiego planu doponóc mogły, ale i o takie, które by mi wstęp do dobrych domów otworzyły. Mając to wszystko na względzie, dopomagaj mi i bądź moim adwokatem u Jana Śniadeckiego. Nade wszystko chialbym mieć list do Czartoryjskiego i Lubeckiego ministra. Tak światło wyłożywszy Ci interes, nie zostaje mi nic więcej, jak polecić się Twojej pamięci i prosić, ażebyś mnie wszystkim przypomniała?.

Krasiński osiemnastoletni - co widać na podstawie listów do Henryka Reeve’a, pisanych po francusku, rzadziej po angielsku - uwydatnia zamiar kształcenia języka. Widać, że stara się o bogactwo języka, o umiejętność opisu, ćwiczy opisy. Widać, jak pracuje nad sobą, nad swoją kulturą literacką, nad francuszczyzną. Zauważa się lektury młodego poety romantycznego. 26 czerwca 1830 roku pisze:

Czyż nie mówitem ci. że Montreux jest nudne, przygnę̧biające? Nie wiem, co ma w sobie ta okolica, ale, jak mówi Lamartine, nie tan serce moje. Masz rację: brzęczenie pszczoły, piosenka strumienia wśród kamyków nie są bynajnmiej godnym akompaniamentem miłości. (...) Wszystko, co wielkie, straszliwe, wznioste. olbrzymie sprawi ulgę namiętnemu sercu, bo wszystko to jednego jest z nim wymiarı; ale te póltony, te rzec by można, krzyżyki i bemole natury, nie wspólgraja z miłością, to znaczy z miłością mlodzieńca w wieku dziewiętnastym. (...) Ale rozumiem, czym mogło być Montreux dla Rousseau, który pisal swoją Heloizq. (...) dla Rousseau, w jego stanie duszy, spokój natury mógł się wydać zbawicnny ${ }^{8}$.

\footnotetext{
'Do Alcksandry Bécu, Krzemieniec, 1+ I 1829. J. Stowacki. Dzicła. red. J. Krzyzanowski, t. 14: Listy' do

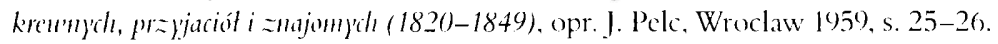

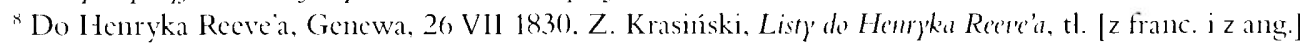
A. Olędzka-Frybesowa. opr. i wst. P. Hertz. t. 1. Warszawa 1980, s. 49.
} 
Zaś 8 lipca tegoż rokı odpowiadal Reeve'owi:

Na pytanie, jak znajdıję twoją francuszczyznę, odpowiem szczerze: w pisaniu nie robisz wcale blędów, styl masz lekki i urozmaicony, francuski w calym znaczeniu tego slowa; w mowie robisz czasem poważne błędy, jak (tytułem przykładı) zawsze używając ,na” zamiast innego słowa, gdy mówisz o czasie".

Natomiast w grudniu 1830 roku Krasiński pisal do angielskiego przyjaciela:

Jedyne chwile spokoju, to te, w którym podziwialem Wenus Medycejską bo to piçkność doskonała, a piçkność, czy to marmurowa, czy z krwi i kości, zawsze przynosi ukojenie w godzinach udręki, jak harfa Dawida w chwilach szaleństwa Saula, a zarazem budzi do życia z apatii. Ale poza tymi krótkimi momentami czulem na przemian to żywy ogień, niemal spopielający mi piersi, to znów chłód stali przenikający w samą głąb serca ${ }^{10}$.

Przebywal wtedy w Rzymie i zachwycał się jego piçknem. Kilka dni później zwierzał się Reeve'owi:

Urodziłem się dla sławy: moja krew jest jak strumień lawy, a serce nigdy nie zadrgato strachem"

Krasiński należał do elity kulturalnej, pięknie się wysławial. Jego listy młodzieńcze do Henryka Reeve’a wskazują na wytężoną, samodziclną pracę nad przygotowaniem się do pisarstwa.

W ciągu dwóch lat Mickiewicz doskonale zapanowal nad językiem. Świadczy o tym jego list do Józefa Jeżowskiego z 9 października 1819 roku. Poeta zdawał sobie sprawę ze swojego samodoskonalenia się w tej dziedzinie:

Moje wiersze dotychczasowe, jeśli miały jaką zaletą, winny ją były po większej części językowi, czyli wydaniu, nad którym starannie pracowałem i w którym cokolwiek nabratem wprawy ${ }^{12}$.

\footnotetext{
"Krasiński do Reerc'a. Genewa, 8 VII 1830, ibidem, s. 74.

"Krasiński do Recvèa. Rzym. 9-12 XII 1830, ibridem. s. 108.

"Krasiński do Reeve"a, Rzym, 18-22 XI1 1830, ibidem. s. 129.

12 Do Józça Jeżowskiego, Kowno, 9/21 X 1819)(s. 38-39).
} 
Mickiewicz wprawdzie pisał to o swoich wierszach, ale „starannie pracowal” takze nad językiem i stylem prozy. Są na to dowody w korespondencji z tych lat. Mickiewicz miał dłuższą drogę do przebycia, ale też byly pewne zalety plynące z faktu, że kultury literackiej i towarzyskiej nie wyniósł z domu i nic był naznaczony pewnymi stereotypami ani ograniczonymi konwencjami. Co nie znaczy, by ich nie znal, czy też nie rozumiat — znal je i odrzucał. W poezji — w imię ,prawd żywych”. Takze prywatnic, w listach ośmieszal wiele razy salonowe, puste grzeczności...

\section{List jako rozmowa. Korespondencja Mickiewicza w świetle badań nad oralnością}

Równolegle do rozpowszechnienia się koncepcji Derridiańskich (w tym m. in. tez Derridy odnoszących się do jego myślenia o opozycjach mowy i pisma i traktujących mowę jako pewną formę pisania - a także prac kontynuatorów, rozwijających tę starą opozycję, ale ujmowaną w nowym sensie: w kontekście archipisania) - w kilku ostatnich dziesięcioleciach badacze jakby od nowa postrzegają oralny clıarakter języka. Konsekwencje przeciwstawiania oralności i pisma uzyskują w ich refleksji nowy wymiar.

Tak zaczyna Anna Opacka swą niemalże pionierską na naszym gruncie książkę Tru'anie i zmienność. Romanty'zne ślad l' oralnościl.3. Jak interesujące i nowe perspektywy może otwierać korespondencja mlodego Mickiewicza - a także cala prawie korespondencja filomatów - przestudiowana w tym aspekcie!

W korespondencji młodego Mickicwicza było trochę studiów warsztatowych: fragmentów prozy, opisów, prób ujęcia wydarzeń swego życia w opowiadanie o jakimś wydarzeniu ciekawym, strasznym, charakterystycznym. Były więc to listy ".literackie”, i Mickiewicz zdawal sobie z tego sprawę, choć in później, tym ımnicj lubił pisywać listy „poetycko-kon-

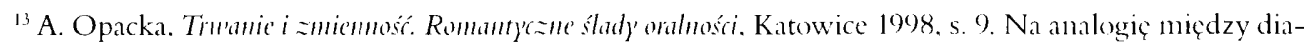
logiem bezpośrednim a wymianą listów oraz na „mówiony” charakter stylu epistolograficznego zwracala

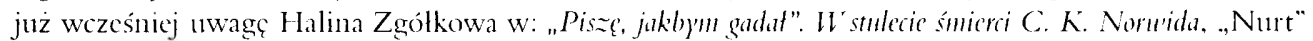
1983, nr 5, s. 21-22. O tym, że list to tekst napisany, a równocześnie .akt mowy”, zob. praca Johna R. Se-

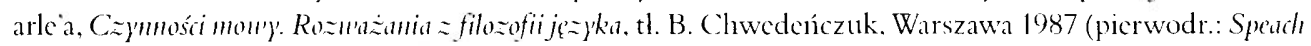
Acts. An Essuy in the Philosophy of Langyuge, Cambridge 1969). Najwcześnicj zaś Stefania Skwarczyniska w Térii listu, Lwów 1937, zw1. s. 211-241, zauważyła, że list, będąc dialogiem. jest zespolem aktów nowy. Nie moge jednak zgodzić się z jej stwierdzenicm o .prynityw'ności teorii listu-mowy" (s. 25). Podobnic

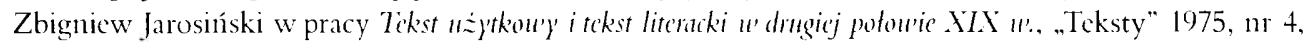
s. 7-27. stwierdza, że list. będąc ..tckstem użytkowym. jest "zjawiskicm", które rozgrywa siç na poziomic jçzyka naturalnego” oraz ,.sanego aktu mówicnia”, czyli „codzicnnej, prywatnej rozmowy”. O strukturze dialogowej listu jako ,aktu mowy” zob. A. Kalkowska, Struktura sk fadmiou'a... op. cit., zwh. s. 34, 65. Por. M. T. Lizisowa. O listach Adama Mickieuricza un aspekcie aktón' mon'?', w: Sztuka pisania. O liścic polskim u' u'iekı XIX, red. J. Sztachelska, E. Dąbrowicz, Bialystok 2000), s. 61-72. 
ceptowate". O wiele więcej jednak jest listów niedbale kolokwialnych, i to tak dalece, że wymagają dziś komentarzy, bo są czasem mało czytelne dla ludzi spoza grona adresatów. Listów pełnych skrótów, przezwisk, szyfrów, aluzji, także dialogów cytowanych bądź wymyślonych. Zwracają uwagę i wiele mówią zwłaszcza owe dialogi. Dlaczego Mickiewicz je wymyśla i zapisuje?

W liście do filomatów z 27 stycznia 1820 roku czytamy:

Przychodzę ze szkoły prawie zawsze zgryziony albo niesfornością, albo, co częściej, tępością uczniów - praca daremna - rzucam się na łóżko i leżę z parę godzin, nic nie myśląc, tylko złując i kwasząc się. Czasem zaś kwasy i złości tak wielkie, iż dosyć przydać dwie uncje jeszcze, żeby się zwariować lub powiesić. Pisząc to, po prawdzie humor sobie zepsulem. Co to będzie na rok przyszły? (...) Ale wiem co, chyba się nauczę pić i po każdej lekcji poobiedniej (seksterna będę mial gotowe) upiję się i spać położę. Nie mówię tego żartem, chociaż wy może śmiać się będziecie - ale i mnie gorzki śmiech porwal — widzę, jak Franciszek narobi krzyku: „Bredzi, sam nie wie co”; a Szwalizer: „Fe! Wino, nic dobrego - pijatyka do zlego prowadzi”, a Szerok zadziwi się, a Jan pisze wiersze z perswazją, a Jeż wyszedl cicho. (...) Koníczę list, jestem zly i śmieję się sam z siebie ${ }^{1+}$.

A w liście z 19 lutego tegoż roku pisał do Czeczota:

Janko! Zdaje się, że już dawno pisałem do ciebie, ale ten tydzień wcale był nie do pisania. Po wyjeździe naszych przybył Franciszek, a stąd ciągła gawędka. Wszystkie okoliczności filomatów opowiadane ledwie mi dały czas list twój ostatni przeczytać. (...) Slyszalem, że miałeś zamiar ruszyć z Franciszkiem. (...) Siedzieć w Kownie byloby ci nudno. (...) Nie ma znajomych, nie ma żadnego zatrudnienia, jedna tylko gawędka ze mną, a i ta by muie, słuchającego, niz ciebie, wiadome opisującego rzeczy, interesowala ${ }^{15}$.

Przez ową dialogowość, wpisaną wprost w list jako rozmowy, a nawet imaginacyjne kłótnie z adresatem, albo też w sposób bardziej dyskretny, przez wykrzykniki, znaki zapytania i inne gesty językowe, listy młodego Mickiewicza ukazują swój rys, jak przypuszczam, najbardziej charakterystyczny: to są listy-rozmowy ${ }^{16}$.

\footnotetext{
1+ Do filomatów. Kowno, 27 I/8 II 1820) (s. 98-99).

${ }^{15}$ Do Jana (izeczota, Kowno. 19) II/2 III 1820) (s. 100).

"Por. J. Pawlik-Swictlikowska, Korespondencju jako tekst sylu iczlly na prapktadzie listou' Mickien'icza, w: Sztuka pisumia... op. cit.. s. 45-59. O ustncj. nicliterackicj sytuacji komunikacyjncj oraz bliskości miçdzy roz-

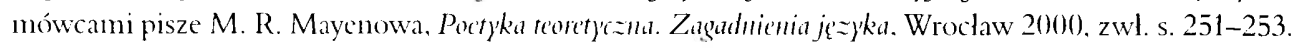


Często zresztą sam Mickiewicz nazywa swój list „rozmową”. Właśnie fakkt, że listy rozmowę choć po części zastępują, Mickiewicz w nich ceni najwyżej. Dlatego często irytowały go listy o kroju literackim; zwłaszcza, także z innych względów, irytowaly go sternowskie „rozdziałki” przesyłane przez Tomasza Zana, co dawno już zauważono. Czego Mickiewicz od swych korespondentów oczekiwał? Kontaktu. Bliskości uczuciowej, intelcktualnej zresztą także, dzielenia się myślami, wierszami, uczuciami. I jakby jeszcze więcej: chciał ,miłych szczególów"' Chciał więc, choć na odleglość, dzielić z przyjaciółmi iclı tryb życia, sposób spędzania czasu, jak bywało, gdy dzielił z nimi za czasów studenckich wiele godzin każdego dnia, a także każdego wieczoru. 5 maja 1820 roku poeta donosil Józefowi Jeżowskiemu:

Wstaję prawie zawsze o czwartej (...) - a dalibóg, czasem przed czwartą, a kawę piję zaraz po piątej. Ranek zajęty pisaniem seksternów, (...) niekiedy balladkami ${ }^{18}$.

Do Czeczota pisał zaś:

Zawinitem tobie mocno, kochany Janic, przybieralem się dlugo, zaledwie dziś przybratem się ostatecznie, a i to nie w majlepszej porze, gdyż teraz bije kwadrans na 11, a do drugiej mam pół arkusza seksterma napisac '1"

A z Franciszkiem Malewskim „rozmawial” w następujący sposób:

Wiesz, gdzie jestem, zgadniesz, jak jestem. Nie lituj się jednak zbytecznie nade mną. Łatwiej jest przywykać aniżeli odwykać. Przywyklem do wielı rzeczy. Kowno staje się dla mnie domem, Wilno gościną, Nowogródek zagranica. Mawnicj duszą byłem w Wilnie. Teraz nie mam tam chęci jechać. Przywykaın do szkoły, bo mało czytam, mało piszę, często myślę i cierpię, a zatem potrzebuję zatrudnienia oślego. W wieczór gram w bostona w pieniądze, (...) muzyki rzadko stucham, bez pieniędzy nie mam interesu grać w karty ${ }^{20}$.

Jerzy Ziomek zauważa, że „slowo mówione” poprzedza pismo „w porządku antro-pogenetycznym" "' Sądzę, iz modzieńcze listy Mickiewicza, będąc słowem pis anym, jakby wracają do formy mówionej. Anna Kałkowska pisze, że list jest „w tómie mówiony” i „wtórnie pisany”, ponieważ „przenosi (...) naturalne sygnały (...) na sztuczny (...)

\footnotetext{
${ }^{17}$ Do Franciszka Malewskiego, Kowno 11/23 XI 1819 (s. 65).

is Do Józefa Jeżowskicgo. Kowno, 5/17 V 1820) (s. 107).

1) 1) Jana Czeczota i Tomasza Zana, Kownolo/22 V 1820 (s. 110$)$.

2" Do Franciszka Malewskiego, Kowno, 20 XI/2 XII I822 (s. 245).

2! Ziomek, Genera scribendi, w: idem, Prace ostatnic. Literatmia i nauka o literaturze, Warszawa 1994, zwt. s. 290.
} 
grunt tekstu pisanego" „22 . Również Halina Zgólkowa stwierdza, iż list jest „tą formą wypowiedzi pisanej, która wykazuje stosunkowo bliskie pokrewieństwo z mówionymi odmianami języka”²3. To w liście „sytuacja komunikacyjna” może być „utożsamiana z sytuacją rozmowy bezpośredniej”-2+. Także Zofia Kawyn-Kurzowa nadmienia, że ,język filomatów jest (...) językiem potocznym, mówionym, językiem prywatnej korespondencj»"25. Zatem uważam, że list romantyczny staje się zdarzeniem słownym, a samo jego pisanie jest próbą za m k n ię c i a jęz y k a w owym zdarzeniu slownym. Dlatego teks ty listów młodego Mickiewicza jako specyficzne formy w y pow ied z i rozpatrujemy w aspekcie mowy mówionej, a jak zauważa Janusz Macicjewski:

List (...) utrwalony pismem na papierze, staje się t e k s t e m, do którego moga micć dostęp także inni ${ }^{20}$.

Jerzy Bartmiński w książce Folk/or - jqzyk - poetyk $a^{27}$, zainspirowany metodologicznie dziełem Waltera Onga Oralność i piśmienność: stow'o poddane tedmologii ${ }^{28}$, doskonale sprawdził owe inspiracje na pozionie języka. Zdaniem Bartmińskiego

tekst (...) ma strukturę dialogową, nastawioną na odbiór audytywny. (...) Dialogowość jest skutkiem ustności, gdyż ustna odmiana języka funkcjonuje i nieustannie odnawia sį̣ w procesie interakcji osób, manifestuje w postaci lańcucha kwestii, kierowanych na przemian ku sobie przez interlokutorów ${ }^{29}$.

\section{Czytany także, iż}

obecność środków komunikacji somatycznej: gesty, mimika, ruchy i uklad calego ciała, tworzą (...) swoiścic zorganizowany subkod ${ }^{30}$,

a to jest cecha charakterystyczna tekstów ustnych. Bartminiski zauważa, że

22 A. Kalkowska. Struktura sk'tudniou'a..., op. cit.. s. 12.

${ }_{23}^{23}$ H. Zgólkowa, „Pisz̨, jakbly'm gadat”..., op. cit., s. 21-22.

${ }^{2+}$ Ibidem.

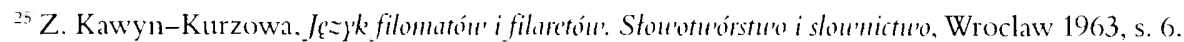

2". J. Macicjewski, List jako formu literack a, w: Szmka pisania.... op. cit., s. 211-218. Zob. też D. Grzesiak, Struk-

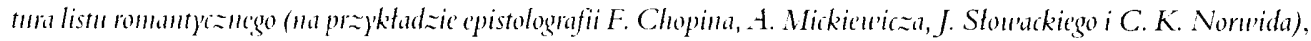
ibide'm. s. 19-31.

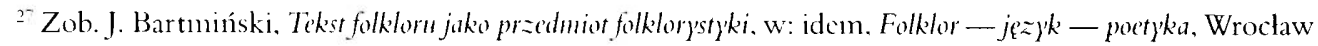
1990, s. $123-1+8$.

2* Zob. W. J. Ong. Orahośí i piśmiemnośr: stou'o poddane techmologii. tl. J. Japola, Lublin 1992 (pierwodr.: Re'thoric, Romance and Tedmology. Studie's in the Interaction and Culture, New York 1971).

${ }^{213}$ J. Bartminiski. Tikst folkloru..., op. cit.. s. 139.

${ }^{31}$ Ibide'm, s. 137. 
w przeciwieństwie do pisanego słowo mówione ma latwy do obserwacji aspekt fizjologiczny, ruchy narządów mowy są postrzegane wzrokowo na równi z ruchami rąk, wyrazem oczu, mimiką twarzy. W tym sensie słowo nówione (...) jest gestem ${ }^{31}$.

Tak więc listy i pamiętniki są głęboko zakorzenione w komunikacji naturalnej, ustnej, poprzez dialogowość, mimo przenoszenia informacji na piśmie.

Natomiast Ong sformulowal pojęcie residunm oralnego, swoistej ,skannieliny” zachowanej w literaturze pisanej. Owo residumm pozwala filologom badać teksty w tym aspekcie oraz stwarza nowe możliwości interpretacyjne, inne perspektywy badawcze, szersze rozumienie związku oralności z piśmicmnością. Ong, zajmując się w rozprawiè owym związkiem, przyjął, iz

stowo oralne (...) nie istniało nigdy w kontekścic jedynie werbalnym, jak to się dzieje ze słowem pisanym. Stowa mówione zawsze stanowią modyfikację calej sytuacji egzystencjonalnej, w którą zawsze włączone jest ciało. (...) Ruchy ciała towarzyszące zwyczajnej wokalizacji nie są w komunikacji oralnej przypadkiem lub wymysłem, są naturalne, a nawet - nieuchromne ${ }^{32}$.

Nieco wcześniej czytany o „zapasic” stownym,

jakim oralność (...) pozostaje zanurzona w świecie ludzkiego życia. Przysłów i zagadek nie wykorzystuje się do prostego przeclowywania wiedzy, one mają wyciągać innych lıdzi do zapasów intelektualnych i werbalnych ${ }^{33}$.

Ong rozwija koncepcję opozycji: „oralnośc” — ,piśmiennośc”. Wedlug niego, do epoki romantyzmu

wydaje siç oczywiste, że głęboko rozunniana tradycja retoryczna reprezentuje dawny świat oralny i tradycję filozoficzną. (...) Całe wicki, aż do (...) romantyzmu (kiedy pęd retoryki zmienia się wyraźnic, o ile nie calkowicie; wystapienie oralne zastępuje pismo) zaangażowanie cxplicite lub nawet implicite

${ }^{31}$ Ibidem. s. 141.

${ }^{32}$ W. J. Ong. Oralnosí.... op. cit. s. 99-100). Na temat związku residumm oralnego ze slowem pisanym zob.: A. B. Lord, Whaśineości litcratury ustncj. tl. P. Czapliński, ..Pamiçtnik Litcracki” R. 81: 1990) z. 1, 5. 281-296;

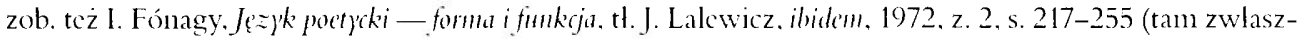

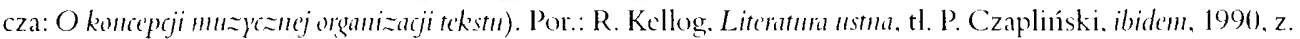

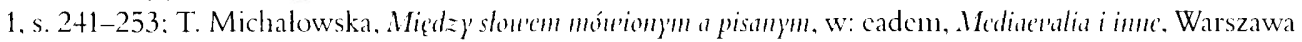
1997, s. $98-153$.

${ }^{33}$ W. J. Ong, Oralnośc..., op. cit.. s. 70 . 
w formalne studium i formalne praktykowanie retoryki jest wykładnią masy oralności pierwotnej w danej kulturze ${ }^{3+}$.

Dla Onga ważna jest zretoryzowana kultura przedpiśmienna, kultura pamięci i jej mit dawności, który adoruje. Ta dawność wpisuje się w estetykę romantyczną, kiedy język literacki staje się gwarantem i wyobrażeniem wspólnoty. To w epoce romantyzmu, wraz z wielkim rozwojem druku, następuje kres residuum oralnego ${ }^{35}$.

Sam Mickiewicz, będąc - jak pisze Anna Opacka - „ogrommie wrażliwy na żywiol oralny"36, wysoko cenil sarmacką gawędę szlachecką oraz Pamiątki Soplicy' Ienryka Rzewuskiego. Zaś residınm orahne poeta — zdaniem badaczki — „zamykał w świecie, języku i konstrukcji gawędy" "j7. Jak powszechnie wiadomo, gawęda, tak jak improwizacja, byla gatunkiem modnym w epoce romantyzmu. W swoich wykładach paryskich mówił o utrwalonych pismem na papierze gestach w Pamiętnikach Jana Chryzostoma Paska, a więc o teatralizacji owej szlacheckiej gawędy:

Gdyby oglaszano wydanie Pamiętnikóu' ze sztychami, zamiast kropek i przecinków, bezużytecznych w utworze, gdzie nie masz regularnych okresów ani zdań, należałoby wprowadzić np. jakieś znaki, które by oznaczały jakieś gesty mówcy. wskazywały, że w tym miejscu podkręca wąsa, w tym dobywa korda, bo gest taki zastępuje czasem słowo, wyjaśnia zdanie ${ }^{38}$.

Mickiewicz cenił pieśni ludowe oraz glośne czytanie. Z muzyką i pieśniami stykał się od najmłodszych lat. Był wrażliwym melomanem, dlatego jego osłuchanie w melodiach wpłynęto na umuzycznienie poezji. Szczególnie III i IV części Dziadóu’ zostały przez autora pomyślane muzycznie, sa przepojone scenami muzycznymi ${ }^{39}$.

Dla Mickiewicza liryka wiązała się z muzyką, było to odesłanie do czasów Orfeusza i Muzajosa, czyli do archaicznej jedności muzyki i poezji, bliskiej romantyzmowi niemieckiemu, jedności idealnej i bardzo wysublimowanej. Bardzo silne residumm oralne jest w Panu Tadeıszu. Kluczowe znaczenie ma tu „koncert nad koncertami” Jankiela z księgi XII, wraz

${ }^{34}$ Ibidem. s. $150-151$.

35 Zob. ibidem. s. 181.

${ }^{3 t_{t}}$ A. Opacka. Tru'unic $i$ zmicmosí .... op. cit., s. 33.

${ }^{37}$ Ibide'm. s. 25.

${ }^{3 \times}$ A. Mickicwicz, Wyklad III. 28 XII 18+1, w: idem, Dzicta. Wydanic Jubileuszowe, red. J. Krzyżanowski, t. 10: Literamma stomianiska. Kinrs drugi, t1. L. Ploszcwski, Warszawa 1955: por. z wyd.: idem. Prelekeje paryskie, wyb., wst. i opr. M. Piwiniska, t. 2, Kraków 1997, s. 27.

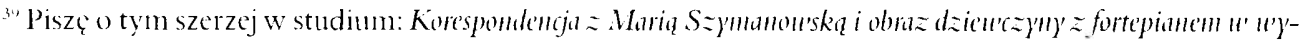

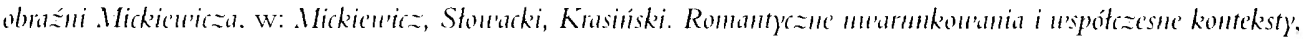
red. E. Owczarz. J. Smulski. Lowicz 20)1, s. 158-165. 
z Polonezem Trzeciego Maja i triumfalna pieśnia powracających legionistów Dąbrowskiego Jeszcze Polska nie zginçła. Anna Opacka, idąc tropem wskazanym przez Onga, pisze:

Pan Tadeusz, nowożytna epopeja, prowadzi w prostej linii do źródła owej oralności, do tradycji epopei homeryckicj. Ta oralna scheda, którą prawa intertekstualnych nawiązań podsıwają z całą intensywnością, w refleksji badaczy od dawna byla wskazywana jako geneza tych tropów. Niemal równie silne nasycenie oralnością wynika też z[e] (...) sktadnika genologicznego Pana Tadeusza: z gawędowości ${ }^{+1 !}$.

To jakby odkrywanie na nowo gawędy szlacheckiej wraz ze sposobem jej opowiadania, z jej „poetyką oralności”, oralną konstrukcją narracji ${ }^{+1}$, czyli zakorzenionym w slowie żywiołem oralnym.

Mickiewicz-gawędziarz mówil swoje listy, a więc ro z ma wial z przyjaciólmi ludzkim językiem, żywą mową, zakorzenioną w tradycji oralnej. W liście do Tomasza Zana z 13 maja 1820 roku czytamy:

Wstaję, ziewam i pociągam się, uaaa! A o zielonoświętnym do Kowna przybyciu? Ani pst! ${ }^{+2}$.

Jest to najjaskrawszy przykład, iz listy modego Mickiewicza przejawiaja cechy ust nego komunikatu, mają oralną narrację, czyli, jak powiedziałbym za Teresą Skubalanką, cechy "stylu mówionego" ${ }^{+3}$, a więc najprostszegro, bądź też za Kazinnierzem Bartoszyńskim, ze są to "zdania kommikowane bezpośrednio" "tt, że autor listów pisał je tak, jak mówil. Myślę, iz poeta mial predyspozycje intelektualne do pisania tego rodzajów listów, iż miat oralną mentahnośćt $\mathfrak{c}^{+5}$. Mickiewicz tak świetnie porozumiewal siç listownie

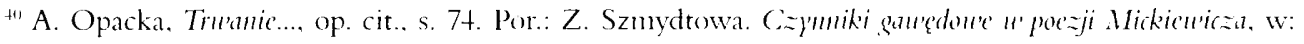
cadem, Rousseau - Mickientiz $i$ inne studia. Warszawa 1961. s. 261-301.

"I Zob. A. Opacka, Tru'unic .... op. cit., zwl. s. 7t-80).

${ }^{+2}$ Do Tomasza Zana. Kowno. 13/25 V 1820 (s. 124). W przyp. 37 (s. 127). czytany: ..W autografic w tym micjscu (...) Mickiewicz narysowal postać z rękami wyciągniçtymi do góry. jakby przeciạgającą siç". Nơtabene E. Sapir w artykule Moura jako rys asobourości (tl. J. Japola, ..Pamiçtnik Literacki” 1972. z. 3. s. 207-218) pisze o problemach z zakresu semantyki wypowiedzi w aspekcic analizy mowy jednostki oraz intuicyjnego badania jcj osobowości. Artykul Sapira wydaje mi siç najbliższy praktyki badawczcj. jaką tutaj stosuję wobec listów mlodego Mickiewicza.

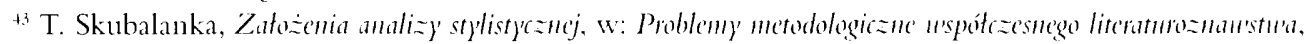
red. H. Markiewicz. J. Slawiński, Kraków 1976, s. 260.

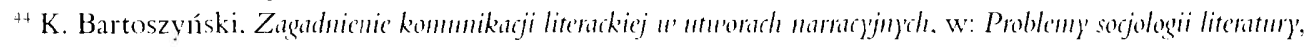
red. J. Slawiński, Wroctaw 1971, s. 130.

${ }^{5} \mathrm{Na}$ temat oralnej wrażliwości Adama Mickiewicza pisze Mikołaj Sokolowski w książce .Król Duch" Juliusza Stourackiego a epopeja stourianska. Warszawa 2004. zwh. s. 206. Por. idem. Tajemmica stou'a. Mickieuriz
} 
z przyjaciólmi, gdyż pisał do ludzi o tym samym z a pa s ie slow ny m, tej samej kulturze, takich samych zainteresowaniach oraz o podobnych doświadczeniach życiowych.

Dokonując próby penetracji stanu badań już opisanego i udokumentowanego obszernie tematu oralności i piśmienności epistolografii, stanalem się dowieść, iż w świetle owych badań konieczna jest nowa lektura młodzieńczych listów Mickiewicza pojmowanych jako rozmowa, oraz pokazać sposoby opowiadan i a zawarte w nich, ukazać proces ksztaltowania się we wczesnej młodości prywatnego języka poety w jego relacjach interpersonalnych. 